\title{
A diverse Upper Jurassic dinosaur ichnofauna from central-west Portugal
}

\author{
OCTÁVIO MATEUS AND JESPER MILÀN
}

\section{LETHAIA}

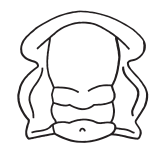

Mateus, O. \& Milàn, J. 2009: A diverse Upper Jurassic dinosaur ichnofauna from central-west Portugal. Lethaia, 10.1111/j.1502-3931.2009.00190.x

A newly discovered dinosaur track-assemblage from the Upper Jurassic Lourinhã Formation (Lusitanian Basin, central-west Portugal), comprises medium- to large-sized sauropod tracks with well-preserved impressions of soft tissue anatomy, stegosaur tracks and tracks from medium- to large-sized theropods. The 400-m-thick Lourinhã Formation consists of mostly aluvial sediments, deposited during the early rifting of the Atlantic Ocean in the Kimmeridgian and Tithonian. The stratigraphic succession shows several shifts between flood-plain mud and fluvial sands that favour preservation and fossilization of tracks. The studied track-assemblage is found preserved as natural casts on the underside of a thin bivalve-rich carbonate bed near the Tithonian-Kimmeridgian boundary. The diversity of the tracks from the new track assemblage is compared with similar faunas from the Upper Jurassic of Asturias, Spain and the Middle Jurassic Yorkshire Coast of England. The Portuguese record of Upper Jurassic dinosaur body fossils show close similarity to the track fauna from the Lourinhã Formation. $\square$ Dinosaur tracks, Lusitanian Basin, Portugal, skin impressions, Upper Jurassic.

Octávio Mateus [omateus@fct.unl.pt], Universidade Nova de Lisboa, Faculdades de Ciências e Tecnologia, Monte de Caparica, Portugal; Museu da Lourinhã, Rua João Luis de Moura, 2530-157 Lourinhã, Portugal; Jesper Milàn [milan@geo.ku.dk], Department of Geography and Geology, Geology Section, University of Copenhagen, Øster Voldgade 10, DK-1350 Copenhagen K, Denmark; Geomuseum Faxe, Østsjollands Museum, Højerup bygade 38, DK-4660 Store Heddinge, Denmark; manuscript received on 16/12/2008; manuscript accepted on 08/06/09.
The Middle to Late Jurassic carbonate platforms of Portugal have yielded several of the largest and most important dinosaur tracksites in Europe (e.g. Dantas et al. 1994; Lockley et al. 1994a; Santos et al. 1994; Lockley \& Meyer 2000), yet only recently the value of dinosaur tracks from Upper Jurassic siliciclastic deposits have been recognized. This paper discusses one such occurrence.

The Lourinhã Formation is exposed in central-west Portugal, mostly near to the town of Lourinhã (Fig. 1). The formation was deposited in the Lusitanian Basin and comprises more than $400 \mathrm{~m}$ of mostly terrestrial sediments, with some coastal intercalations (Kullberg et al. 2006) deposited during the early rifting stage of the Atlantic Ocean in latest Jurassic, Tithonian-Kimmeridgian times (Hill 1989). The sediments consist predominantly of thick beds of red and green clay, interbedded with massive fluvial sandstone bodies and heterolithic beds. The sandstone bodies are horizontally extensive, lenticular beds that in some instances are traceable for several kilometres in the exposed cliff sections along the coast. The sandstone lenses have been interpreted as distal alluvial fan facies originating from periods of extensive faulting (Hill
1989). The Lourinhã Formation contains a highly diverse vertebrate fauna comprising fish, amphibians, turtles, pterosaurs, crocodiles, dinosaurs and mammals (Antunes 1998; Antunes \& Mateus 2003; Mateus 2006; Mateus et al. 2006), as well as dinosaur nests, eggs and embryos (Antunes et al. 1998; Mateus et al. 1998). The formation is also known for its fossil vegetation, namely plant fragments and large fossilized tree logs (Pais 1998). Yagüe et al. (2006) proposed a lithostratigrapic scheme for the continental Upper Jurassic of the Lusitanian basin, which includes the Bombarral, Sobral and Alcobaça Formations (including Consolação and Praia da Amoreira- Porto Novo Members) within the Lourinhã Group.

The succession shows abundant shifts between unconsolidated flood-plain mud and fluvial sandstone that favour recognition of fossil tracks. Within the last years, more than 30 well-preserved single tracks and small trackways of sauropods, theropods, thyreophorans and ornithopods have been discovered, both preserved in-situ on the original sedimentary surfaces and on loose blocks fallen to the beach caused by the extensive coastal erosion (Antunes \& Mateus 2003; Milàn et al. 2005; Mateus \& Milàn 2008). 


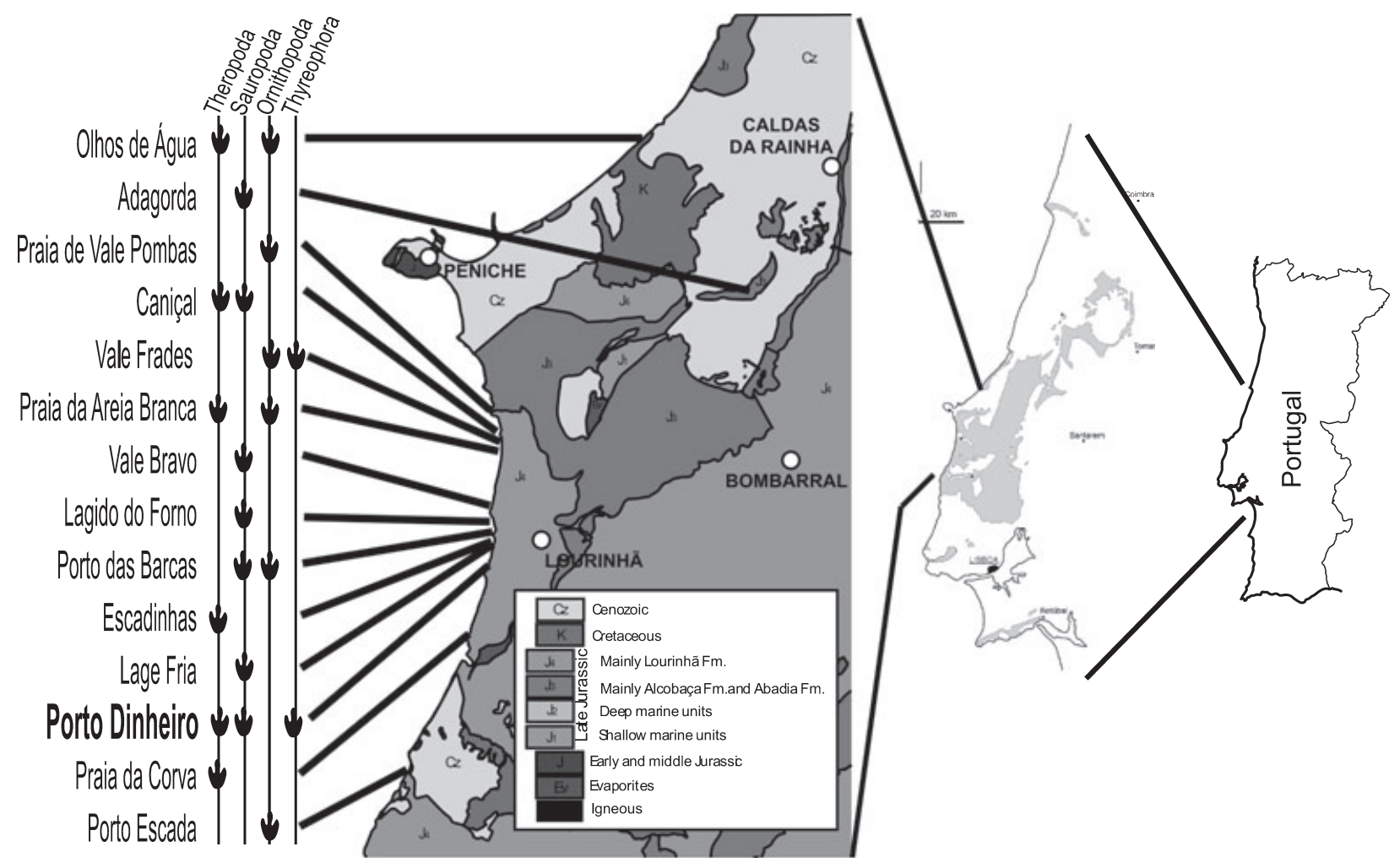

Fig. 1. Geological map of central-west Portugal (based on Alves et al. 2003) with main track localities depicted.

The aim of this study is to describe a new multitaxon track assemblage found in the coast cliffs just south of the locality of Porto Dinheiro, to compare it with similar track faunas from the Middle Jurassic of England and the Upper Jurassic of Spain, and to compare it with the known dinosaur skeletal record from the Lourinhã Formation and the Upper Jurassic of Portugal.

\section{Porto Dinheiro track assemblage}

\section{Identification of tracks}

Theropod and ornithopod dinosaurs are both functionally tridactyl, and both leave tridactyl tracks, that at first glance can seem difficult to distinguish them. Theropod tracks are characterized by being longer than they are wide, with long narrow, often tapering, digits ending in long, sharp claw impressions (Moratalla et al. 1988; Thulborn 1990; Lockley 1991), and the divarication angle between digits II and IV is normally $50-60^{\circ}$, but can be as low as $35^{\circ}$ and up to $75^{\circ}$ (Thulborn 1990). Theropod trackways are set in a narrow gauge pattern, with high pace angulations, approaching $180^{\circ}$ and a tendency for the feet to show slight inward rotation (Moratalla et al. 1988;
Thulborn 1990; Lockley 1991). Ornithopod tracks are generally wider than they are long, the digits are short and rounded, and when present the imprints of the claws are blunt and rounded. The divarication angle between digits II and IV are normally in excess of $60^{\circ}$, their trackways are set in a broader pattern than theropods, and the feet often show an outward rotation (Moratalla et al. 1988; Thulborn 1990; Lockley 1991).

Stegosaur tracks are poorly known in the fossil record, and some confusion exists about the identification of stegosaur tracks. (Thulborn 1990; Whyte \& Romano 1994, 2001; Lockley \& Hunt 1998; Long 1998; Gierlinski \& Sabath 2002; Lires et al. 2002; García-Ramos et al. 2006, 2008; Whyte et al. 2007; Lockley et al. 2008) The track named as Deltapodus brodricki (Whyte \& Romano 1994, 2001), however, is a close fit for the flesh-out morphology of the stegosaur pedal skeleton. Deltapodus is characterized by entaxonic, crescent-shaped manus impression that is approximately twice as wide as long, and may have the impression of an inward-directed pollex claw. The pes of Deltapodus is generally triangular to subtriangular in outline, tridactyl and mesaxonic, with impressions of short, bluntly rounded digits and a maximum width across the base of the digit impressions (Whyte \& Romano 1994). 
Sauropods display an extreme degree of heteropody in their tracks, the sauropod manus track is crescent shaped, normally without indications of free digits, except for, in some genera, a prominent inward-directed pollex claw. The pes track is elongated, entaxonic, and can display from three to five short outwardrotated digit impressions (Thulborn 1990; Lockley 1991; Lockley et al. 1994b; Wright 2005). The manuspes size ratio varies from 1:2 (Santos et al. 1994) to 1:5 (Lockley et al. 1994b), and sauropod trackways can be roughly divided into wide- and narrow-gauge trackways (Lockley et al. 1994b).

During field work in the summers of 2005 and 2006, several casts of dinosaur tracks were discovered on the beach and in the cliff section approximately $500 \mathrm{~m}$ north of the beach at Porto Dinheiro (Fig. 1). All the tracks were found as casts on the underside of large blocks fallen from a laterally extensive marine carbonate bed near the top of the cliff section (Fig. 2). This carbonate bed is the upper of two distinct $0.5-\mathrm{m}$ thick carbonate layers, rich in the bivalves Isognomon and Eomiodon securiformis, and represents short, marine transgressions. The Isognomon/Eomiodon layer with the tracks can be traced for several kilometres along the coastal cliffs, and the upper layer represent the interface between the Praia da Amoreira-Porto Novo Member and the Sobral Formation (= Praia Azul Member), recognized as Upper Kimmeridgian to Early Tithonian in age (Leinfelder 1987). The carbonate bed displays abundant tracks, and seven blocks with tracks were found within a distance of $20 \mathrm{~m}$ from each other, as well as several loose scattered down the cliff face. The preservation of the tracks is unusual in that the tracks are located on the underside of a marine limestone bed containing numerous large bivalves and large Thalassinoides burrows. The casts of the tracks contain several of the large bivalves, and bivalves are present between the digit impressions in some of the tracks, suggesting that the tracks were emplaced in shallow water or during a period of sub-aerial exposure.

The first track to be discovered from the locality was a large well-preserved cast of the right pes from a sauropod (Fig. 3), followed by several tridactyl theropod tracks, a stegosaur track and a giant-sized theropod track were found within a $20 \mathrm{~m}$ stretch of fallen blocks on the beach. Later, several tracks and fragments of tracks were recovered in loose blocks on the cliff face.

\section{Sauropod tracks}

Several natural casts of tracks was indentified as sauropod pes tracks as they range in size from 58 to $105 \mathrm{~cm}$ in length, are entaxonic, elongated piriform, with impressions of short, pointy, outward facing digits (Figs 3-5). Some specimens show evidence of short blunt claws and a division into digital pads (Figs 3, 4). The heel area of the foot consists of a large rounded pad, separated from the digit impressions by a more shallowly impressed area.

The casts of the individual digits, including the ungual insertion in digit II, are preserved exquisitely in the best-preserved cast (Fig. 3). Assuming that this
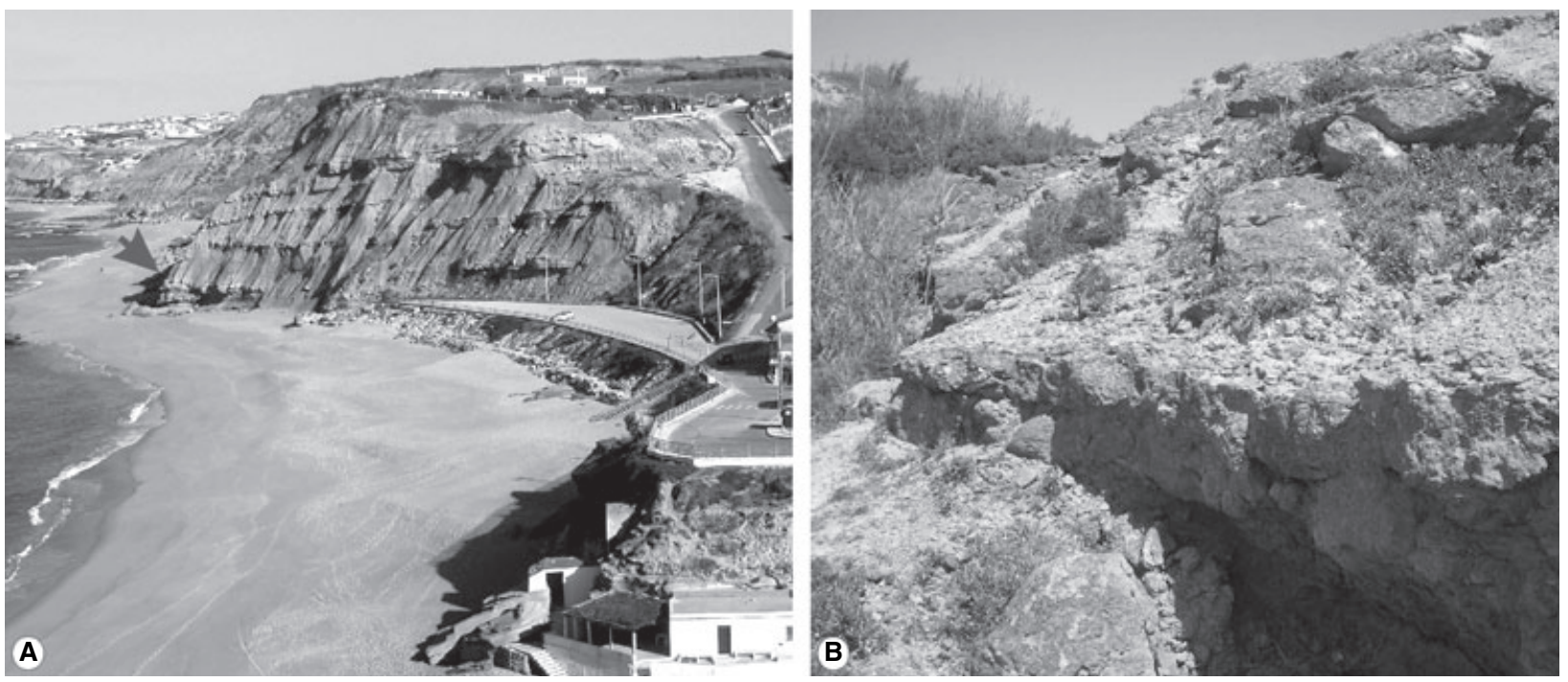

Fig. 2. Photography from the track-bearing locality, approximately $500 \mathrm{~m}$ north of Porto Dinheiro. A, the Upper Jurassic Lourinhã Formation is prominently exposed in steep cliff sections, and consists of thick beds of red and green clay, intercalated with horizontally extensive fluvial sandstone beds. Arrow indicates the location of the track fallen from the cliff section. B, the track assemblage originates from the underside of a prominent greyish, bivalve-rich marine carbonate bed located at the top of the cliff section. 

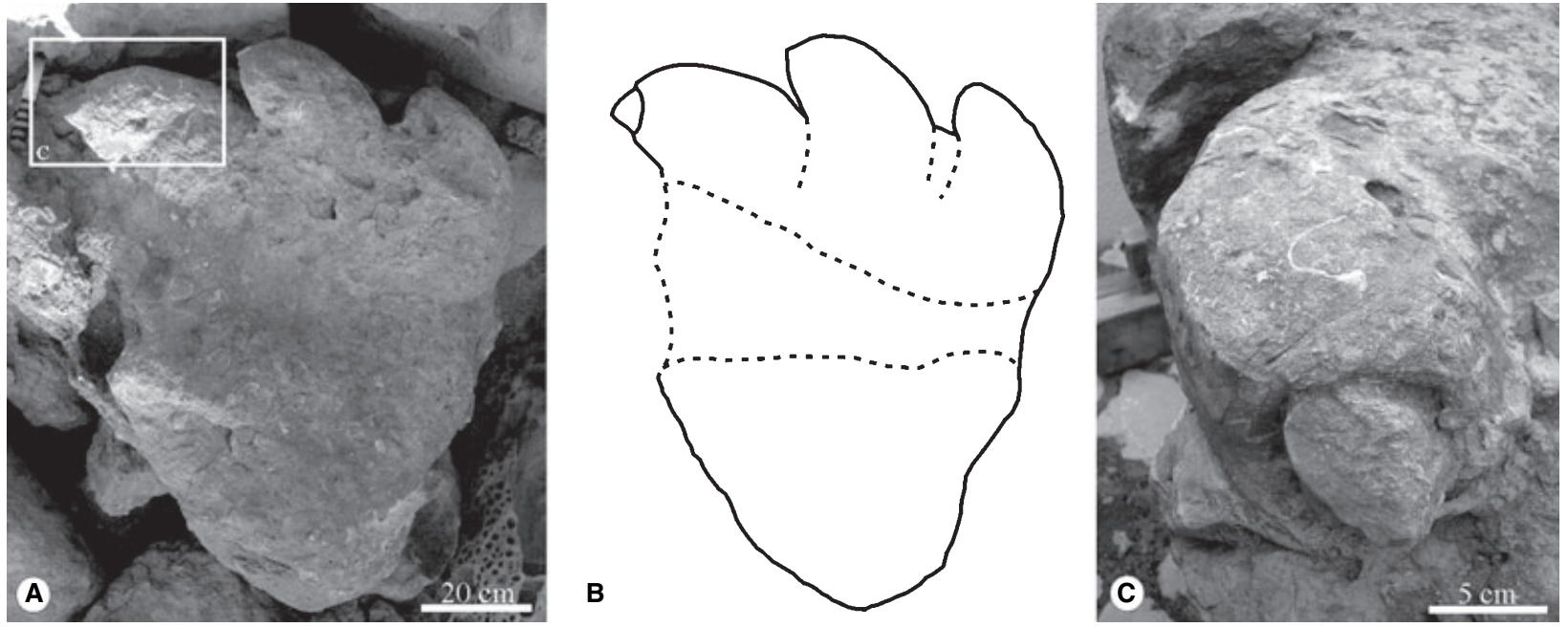

Fig. 3. A, natural cast of a large sauropod pes track from Porto Dinheiro. The track measures $105 \mathrm{~cm}$ in length and the casts of the digit impressions are sharp, well-defined and show the digits to be outwards directed. B, interpretative drawing of the track, showing the track to be divided into a triangular heel pad and, separated from the digital pads by a shallower area. C, close-up, head-on view of the cast of digit II on the large pes in A. This cast perfectly shows that the ungual is proximally enclosed by the fleshy digit.

preservation closely fits to only the basic morphology of a fleshed-out sauropod foot with toes, this track contributes to the understanding of an aspect of soft tissue morphology of sauropod feet, and shows the ungual is proximally enclosed by the soft tissue (Fig. 3). Perfect impressions of the skin are present on several patches on the underside and sides of the best- preserved casts (Figs 4, 6). Two different types of skin pattern are observed on the underside of the pes casts. In the palmar surface of the feet, the skin pattern is rough and tubercular with the scales arranged in a hexagonal pattern an each scale tubercle from 2 to $3 \mathrm{~cm}$ in diametre (Fig. 6). On the sides, the skin pattern becomes pointier with overlapping scales, with

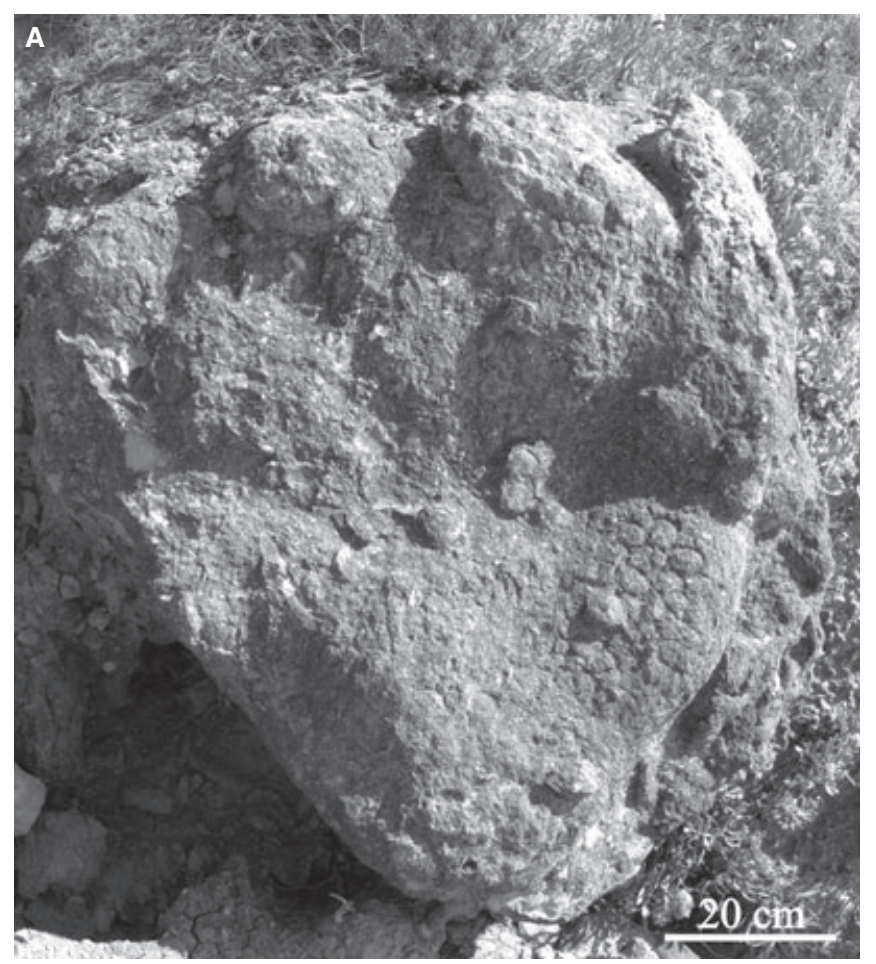

B

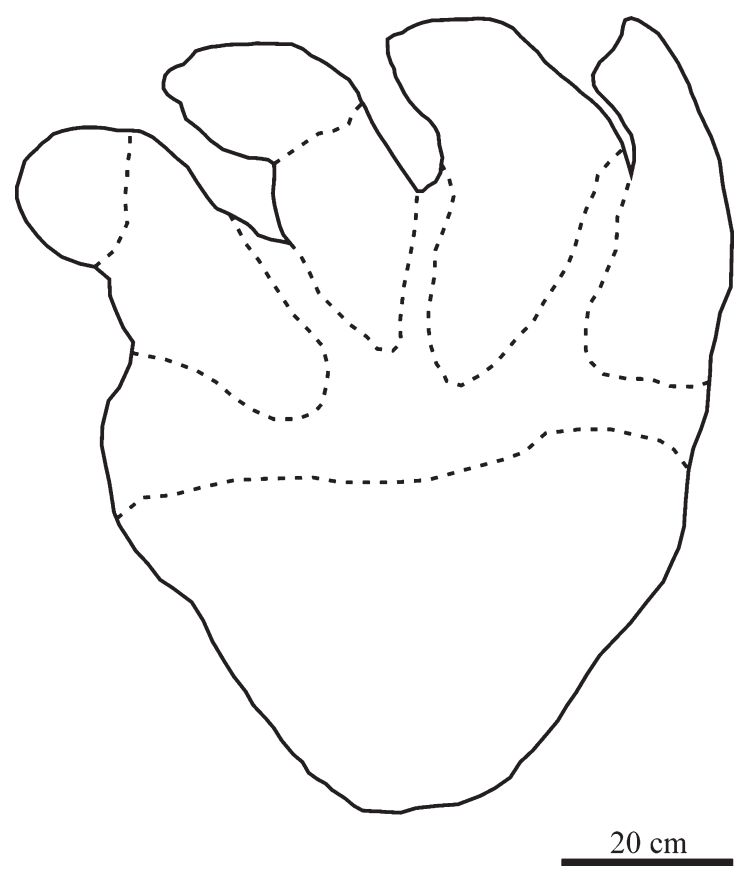

Fig. 4. A, large cast of a complete sauropod pes with impressions of four digits and well-preserved skin impressions in the the heel area. Notice the heel pad is separated from the digital pad impressions by a shallower area. B, interpretative drawing. 


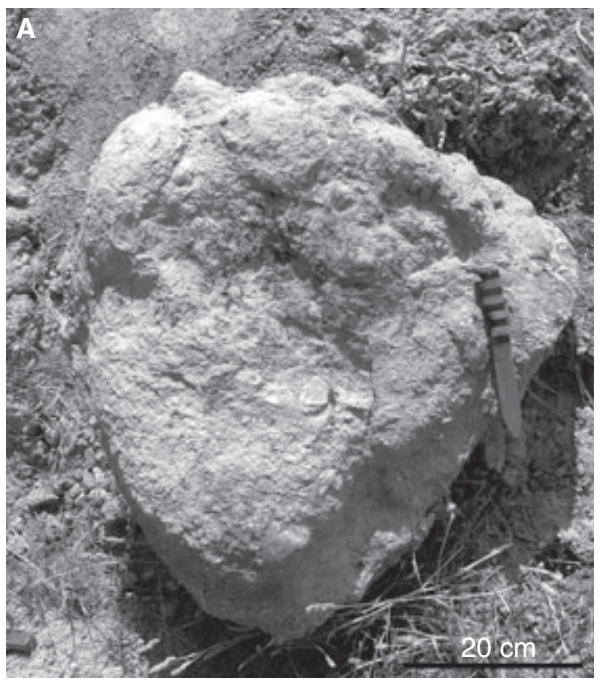

B

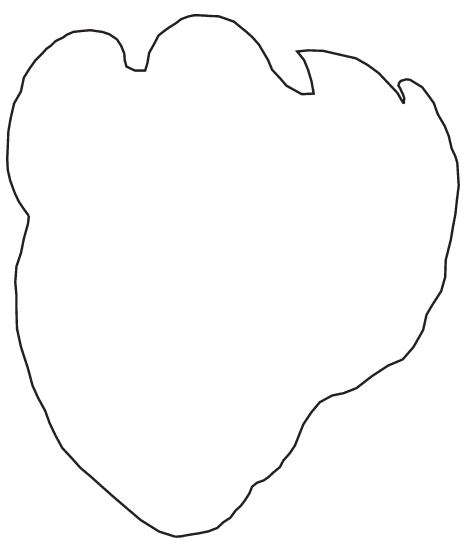

$20 \mathrm{~cm}$

Fig. 5. A, cast of a smaller sauropod pes, measuring only $58 \mathrm{~cm}$ in length. B, interpretative drawing.
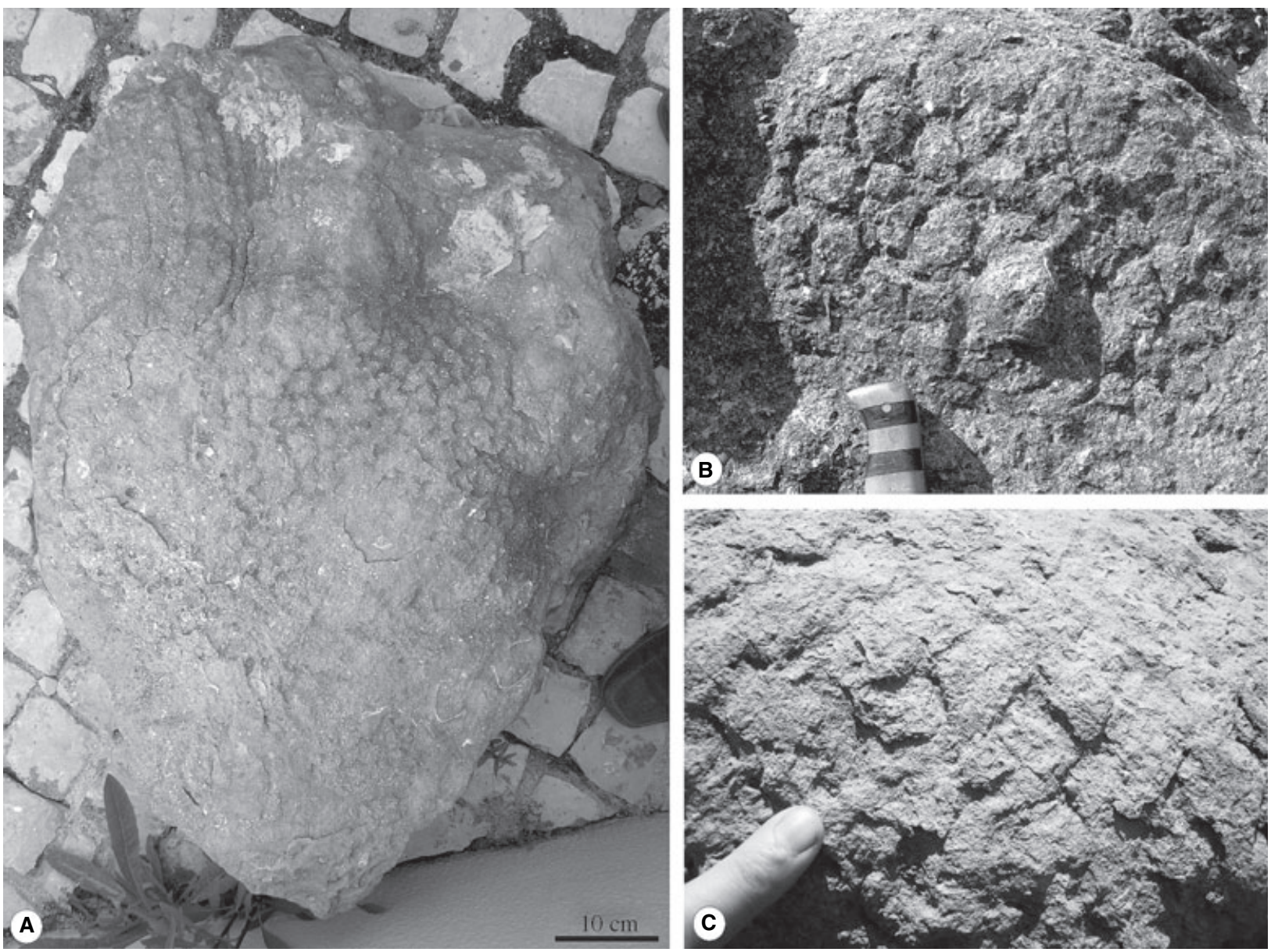

Fig. 6. Skin impressions from sauropod tracks. A, large track where the foot has slid through the mud, causing the formation of uni-directional elongated striations along one side of the track, while the palmar surface of the track is covered with the cast of a rough scaly skin. B, close up of the scaly skin impression. The skin scales covering the palmar surface of the foot are $2-3 \mathrm{~cm}$ in size and are arranged in a hexagonal pattern. $\mathrm{C}$, on the side of the cast the skin tubercles appear as triangular overlapping scales. 
the pointy end facing upward (Fig. 6C). On the walls of the cast, the scaled skin resembles a pattern of elongated parallel striations formed by the foot sliding sideways through the sediment (Fig. 6A).

Several additional casts of sauropod pes imprints and fragments of casts of various sizes were scattered down the cliff face. Yet, no casts of manus impressions have to date been identified with certainty.

\section{Theropod tracks}

Numerous natural casts of elongated, tridactyl mesaxonic tracks ranging in size from 30 to $79 \mathrm{~cm}$ in length are identified as theropod tracks (Figs 7-9). These tracks fall into three distinct size groups, the most abundant type is $30-35 \mathrm{~cm}$ long, with a low angle of divarication between the impressions of the outer digits. The tracks are slightly longer than wide and the impressions of the digits are long and cigar shaped, and in the best-preserved specimens, terminating in impressions of sharp claws (Fig. 7). The casts of the tracks are 5-12 cm deep, and some of them are deformed as if the foot slid sideways when it was brought down through the soft mud. The small tracks show only a very weak division of the digits into digital pads, which together with the cigar-shaped digit impressions refers them to the Jurassic ichnogenus Therangospodus (Lockley et al. 2000).

Two larger tracks, 52 and $54 \mathrm{~cm}$ long, respectively, represent a group of larger theropod trackmakers with long, narrow digit impressions that end with sharp claw impressions. The $52-\mathrm{cm}$ track lacks the distal parts of the two outer digit impressions so the total width of the track is not measurable. The track is $54 \mathrm{~cm}$ long $46 \mathrm{~cm}$ wide (Fig. 8). One of the outer digit impressions is almost twice as wide as the others. This phenomena is previously described from the Lower Cretaceous track Bueckeburgichnus maximus Kuhn 1958, from the Wealden of Germany (Lockley 2007), and in the Maastrichtien track Tyrannosauripus pillmorei from New Mexico (Lockley \& Hunt 1994) where in both cases digit II is significantly broader than digits III and IV (Lockley 2007). In the present case, however, we interpret the broadening of the digit impressions as double imprinting of the digit or partly overstepping of another track. A single giant-sized cast of a theropod track is $79 \mathrm{~cm}$ long, measured from the tip of digit III to the proximal end of the metatarsal pads (Fig. 9). The distal part of digit IV is broken off, and without the missing part of the digit, the track is $60 \mathrm{~cm}$ wide. A partial impression of the metatarsus is preserved, protruding $15 \mathrm{~cm}$ further back from the track, giving it a total length of $96 \mathrm{~cm}$. The impressions of the digits are slender and the divarication angle between digits II and IV is estimated at $46^{\circ}$. Digit III has a lateral swelling in the middle of the digit (Fig. 9), similar to what is observed in Tyrannosauripus pillmorei (Lockley \& Hunt 1994), but whether it represents pathology, or is a taphonomic artefact is at present uncertain.
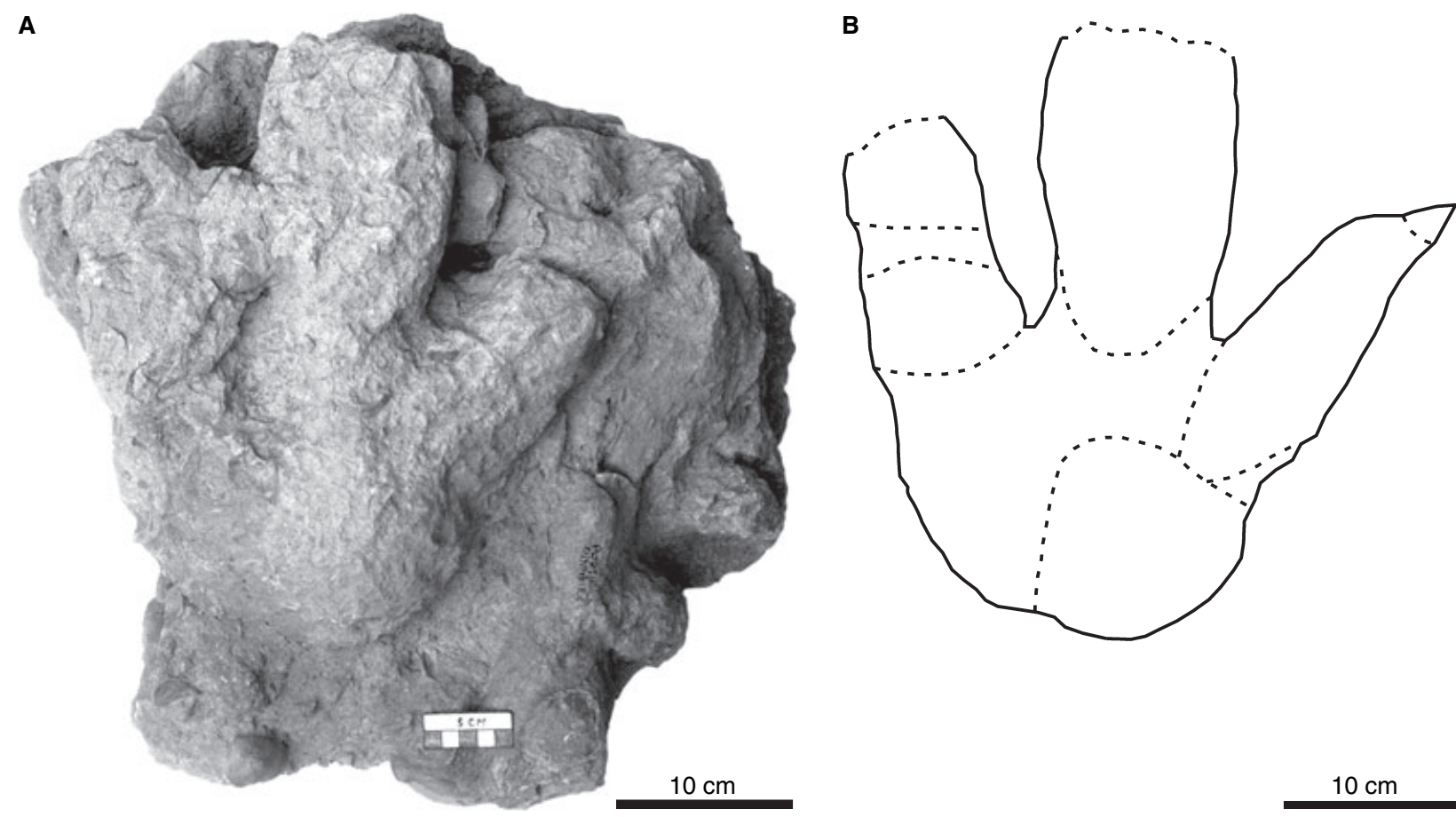

Fig. 7. A, the natural cast of the small tridactyl track is relatively well-preserved with impressions of long, slender, cigar-shaped digits. The track is $34 \mathrm{~cm}$ long and $32 \mathrm{~cm}$ wide. $\mathrm{B}$, interpretative drawing. 

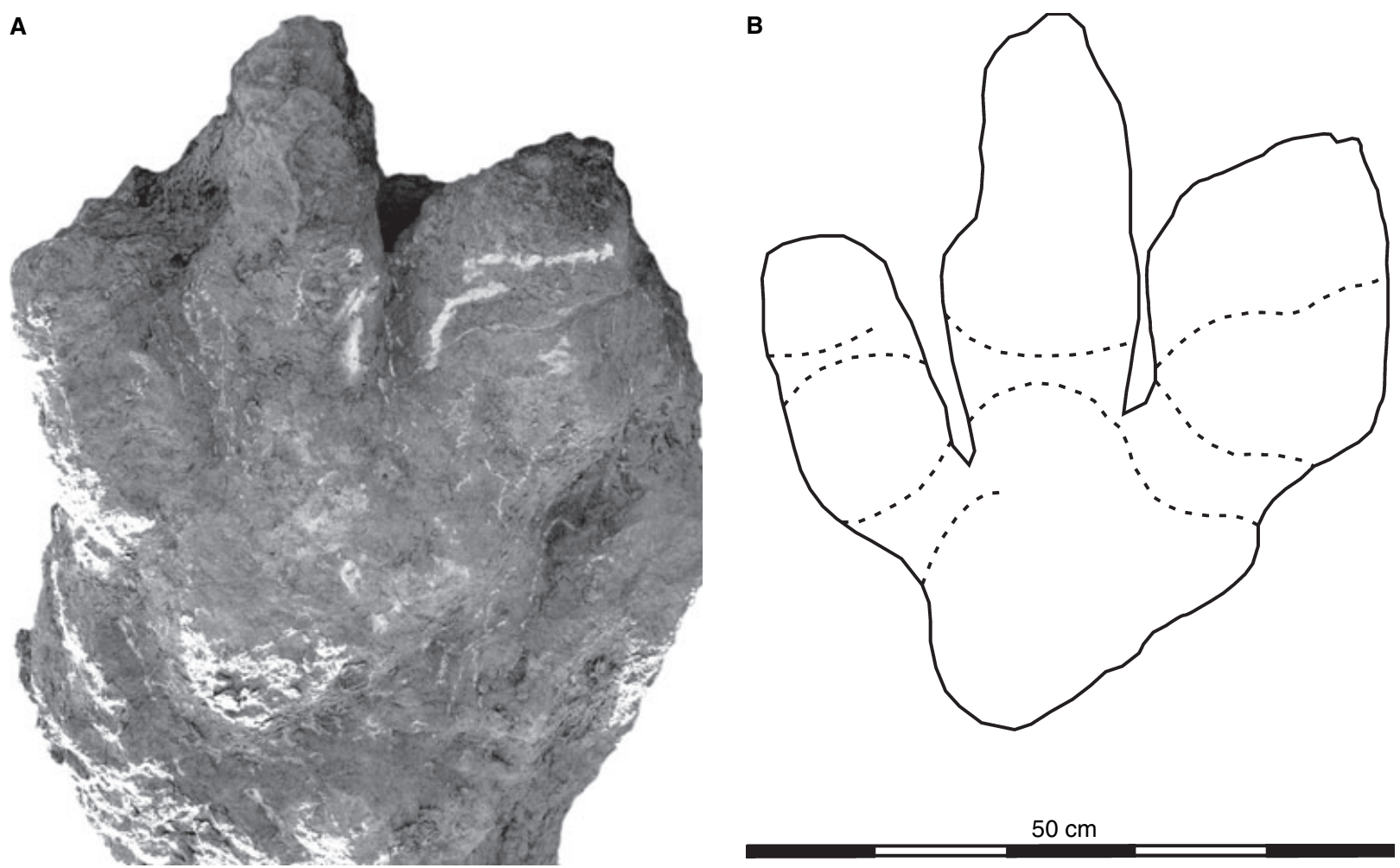

Fig. 8. A, medium-sized theropod track. This track is $54 \mathrm{~cm}$ long and $46 \mathrm{~cm}$ wide, with long slender digits divided into digital pads and terminating in sharp claws. B, interpretative drawing. The impression of the right digit is double as wide as the left digit and is interpreted as double imprinting of the digit.

In addition, a single cast of a deeply impressed theropod track was found on the sloping part of the cliff section in connection with the other tracks. The cast of the track is $40 \mathrm{~cm}$ long, $37 \mathrm{~cm}$ wide and $15 \mathrm{~cm}$ deep. The impressions of the digits are narrow and have preserved grooves formed by the claw being dragged down through the sediment. Fine striations from the scaly skin, $2-3 \mathrm{~mm}$ wide, are present on the outer side of the digit impressions. This track is preserved as a natural cast of fine-grained sandstone, and does not originate from the same stratigraphic level as the other tracks.

\section{Stegosaur track}

A single well-preserved natural cast of a tridactyl mesaxonic track, with very short, rounded, hooflike, forward facing digit impressions and a broad massive heel area is referred to Deltapodus brodricki, an ichnogenus made by a stegosaurian trackmaker (Whyte \& Romano 1994, 2001). The cast of the track is $42 \mathrm{~cm}$ long, $32 \mathrm{~cm}$ wide, and on average $12 \mathrm{~cm}$ deep (Fig. 10). The cast is deepest in the area of the toes and the heel, with the middle part of the track less impressed into the substrate. A weak division into pads are present at the digits and faint striations from the skin being dragged through the sediment are sporadically preserved in the trackwalls. The track elongation and the digit count suggest that it is the pes print. This is the only stegosaur track found at the Porto Dinheiro locality, but a similar specimens have been found in connection with a large ornithopod track at the nearby beach of Vale Frades (Mateus \& Milàn 2008), and additional hitherto undescribed specimens from the Lourinhã Formation are stored in the collection of Museu da Lourinhã. The dimensions of the track, $42 \mathrm{~cm}$ in long and $32 \mathrm{~cm}$ wide, fall well within the normal size of Middle Jurassic Deltapodus specimens from the Yorkshire coast of England (Whyte et al. 2007), and the Upper Jurassic of Asturias, Spain (García-Ramos et al. 2006; Lockley et al. 2008).

The record of stegosaur tracks is, by far, scarcer than what is observed in other dinosaur groups, and Deltapodus is so far restricted to the floodplain systems of the Middle Jurassic Yorkshire Coast of England (Whyte et al. 2007), the Upper Jurassic of Asturias, Spain (Lires et al. 2002; García-Ramos et al. 2006, 2008; Lockley et al. 2008), the Upper Jurassic of Portugal (Mateus \& Milàn 2008) and Utah, North America (Milàn \& Chiappe 2009). 

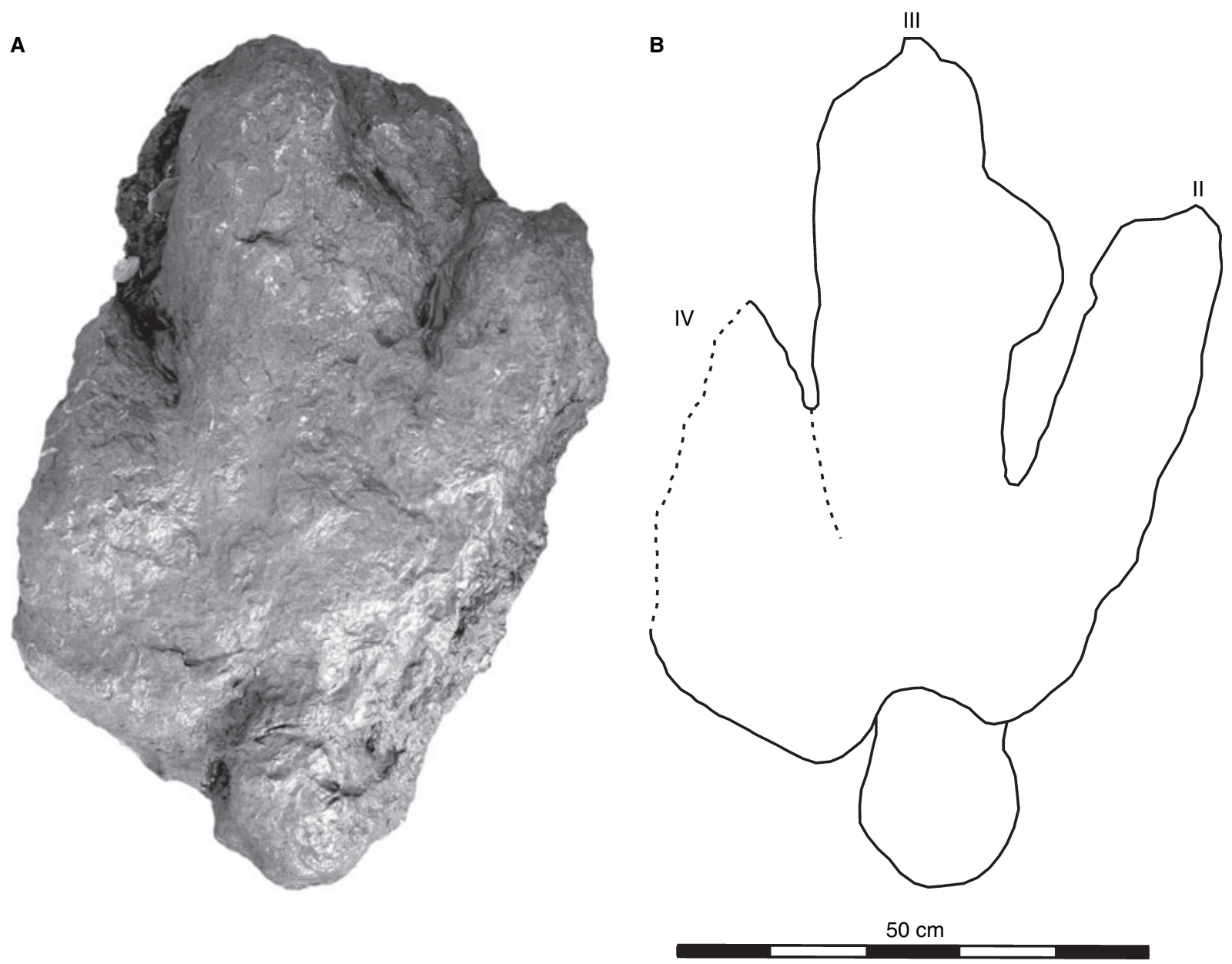

Fig. 9. A, track from a large-sized theropod. The track measures $79 \mathrm{~cm}$ in length and $60 \mathrm{~cm}$ in width without the missing distal part of digit IV. When the length of rearward protruding metatarsus impression is added the total length of the track is $96 \mathrm{~cm}$. This track is among the largest theropod tracks ever found in the Jurassic. B, interpretative drawing.

A

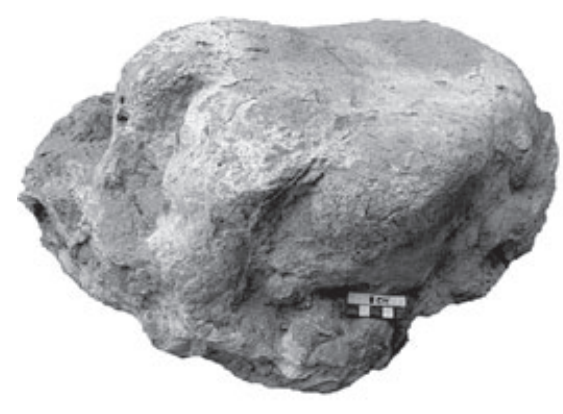

B

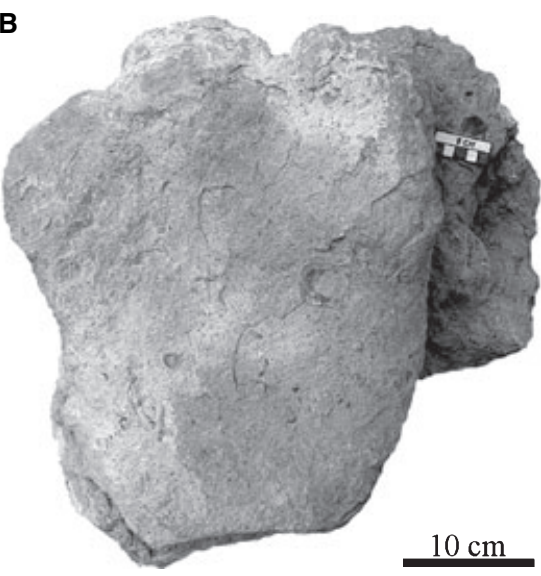

C

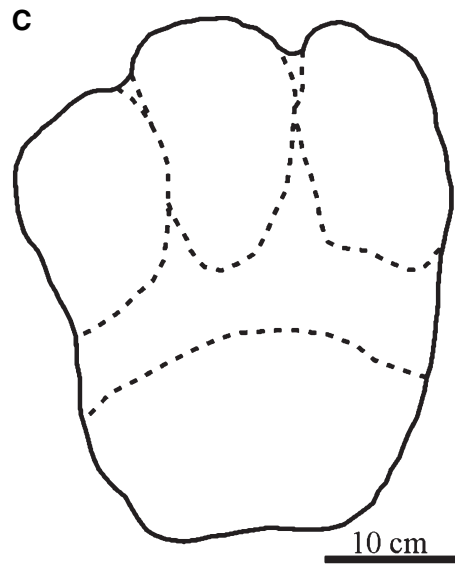

Fig. 10. A, natural cast of a stegosaur pes print. The foot had sunk to a considerable depth in the sediments forming steep trackwalls with preserved striations from the skin. B, the track is tridactyl, $42 \mathrm{~cm}$ long and $32 \mathrm{~cm}$ wide, and close to symmetrical along the midline. The casts of the digits are short, blunt and forward facing. The sole of the foot shows a weak division into a rounded heel pad and three elongated pads at the digits. C, interpretative drawing of the track with pedal pads indicated by broken lines. 


\section{Dinosaurs from the Lourinhã formation}

Since 1863, the Lourinhã Formation has provided abundant well-preserved skeletal remains of a diverse dinosaur fauna. Table 1 summarizes the Upper Jurassic dinosaurs described from Portugal and additional information about the type specimen and locality is provided when it concerns a type specimen described from Portugal. The exposures around Porto Dinheiro (Lourinhã Municipality) have provided the majority of the dinosaur finds from the Upper Jurassic of Portugal, and the locality is the stratotype for Dinheirosaurus lourinhanensis and Trimucrodon cuneatus, and the mammal Pinheirodon. The surrounding areas have in addition provided remains of thyreophorans, Dacentrurus, aff. ornithopods, Dryosaurus and Phyllodon, several genera of large and small theropods including Lourinhanosaurus, and at least four different sauropods (Table 1).

\section{Discussion - tracks and trackmakers}

Tracks and trackways are biogenic sediment structures, dependent on different taphonomical processes than bodyfossils in order to be preserved, and are commonly found in sedimentary settings where few or no body fossils are preserved. The Lourinhã Formation is a rare example where both tracks and skeletal remains are found well preserved and can supplement each other in the faunal descriptions. The possible track makers can be tentatively identified considering the well-preserved morphology and dimensions of the tracks, and the estimated body sizes in the list of Upper Jurassic dinosaurs from Portugal (Table 1). The suggested trackmaker for the small theropod tracks $30-40 \mathrm{~cm}$ long is Lourinhanosaurus antunesi, which is a small- to medium-sized tetanuran theropod with an estimated total body length of 4-6 m (Table 1). Two possible trackmakers exist for the medium-sized theropod tracks with lengths of 52$54 \mathrm{~cm}$. A Ceratosaurus sp. with an estimated body length of 5-7 m and the allosaur Allosaurus europaeus is estimated to be $6-8 \mathrm{~m}$ long (Table 1). The giantsized theropod track with a total length of $79 \mathrm{~cm}$ is tentatively referred to Torvosaurus which, with a body length of 8-12 m, was the largest theropod in the world during the Upper Jurassic. An almost complete Torvosaurus maxilla, $63 \mathrm{~cm}$ long, from an animal with an estimated skull length of $158 \mathrm{~cm}$ was found in the Lourinhã Formation in 2003 (Mateus et al. 2006), and limb bones from a similar sized animal has previously been found in the area (Mateus et al. 2006). Following the formula suggested by Alexander (1976), that the hip height of a dinosaur can be estimated as four times the length of the foot, the animal responsible for the large track stood $3.5 \mathrm{~m}$ tall at the hips. A theropod track with an estimated total length of $82 \mathrm{~cm}$ found in the Upper Jurassic of Asturias, Northern Spain (García-Ramos et al. 2006) is morphologically different, in that the digit impressions is longer and more slender than in the Portuguese specimen. This suggests that more than one type of giant theropod existed in Europe during the latest Jurassic. The Upper Jurassic theropod tracks from Portugal and Spain are the largest Jurassic theropod tracks in the world, and only the tyrannosaur track Tyrannosauripus pilmorei from the Maastrichtian of New Mexico is larger, being $86 \mathrm{~cm}$ long and $64 \mathrm{~cm}$ wide (Lockley \& Hunt 1994). However, if the additional length of the metatarsus impression is included in the specimen from Porto Dinheiro, then the total length of the track is $96 \mathrm{~cm}$. When including the length of the metatarsus, the large theropod track from Asturias is $103 \mathrm{~cm}$ long (GarcíaRamos pers comm. 2009).

The sauropod track lengths range from $58-105 \mathrm{~cm}$, and are dominated by tracks of almost $1 \mathrm{~m}$ in length. Several sauropod trackmakers are known from the Lourinhã Formation (Table 1), and the diplodocid Dinheirosaurus lourinhanensis with an estimated total body length in excess of $20 \mathrm{~m}$ was excavated within $500 \mathrm{~m}$ from the track locality, making it a possible trackmaker.

Two stegosaurs are known in the Upper Jurassic of Portugal: Dacentrurus armatus and Stegosaurus cf. ungulatus (Escaso et al. 2007). The knowledge about Dacentrurus autopodium morphology is not sufficient to be able to infer differences between Dacentrurus and Stegosaurus tracks. As far as the trackmaker is concerned, the stegosaur tracks of Porto Dinheiro are attributed to Stegosauridae indet.

No tracks from ornithopod dinosaurs have so far been found at the Porto Dinheiro locality, but tracks and trackways from ornithopods are known from the nearby cliff sections of Porto das Barcas (Antunes \& Mateus 2003) and Vale Frades (Mateus \& Milàn 2008), and it is likely that ornithopod tracks will turn up during future research and excavations in the area around Porto Dinheiro.

The polygonal texture of the skin impressions is similar to that described in sauropod tracks from the Morison Formation in Utah and Wyoming (Lockley \& Hunt 1995; Platt \& Hasiotis 2006), the Upper Jurassic of Asturias, Spain (García-Ramos et al. 2002, 2006) and the Cretaceous Haman Formation, Korea (Yang et al. 2003; Lockley 2007), where the skin impressions initially were misidentified as the marine trace fossil Paleodictyon (Yang et al. 2003). 


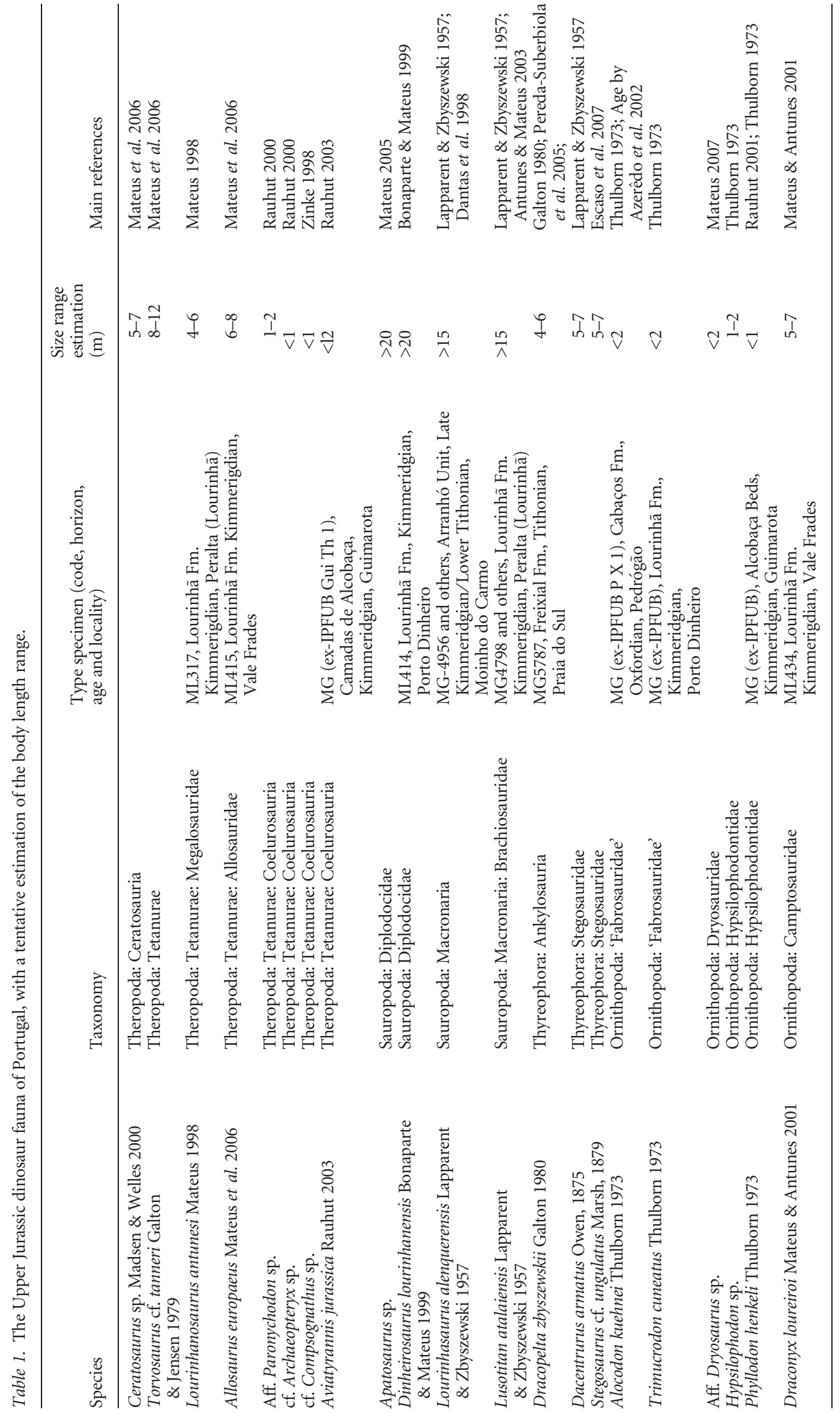



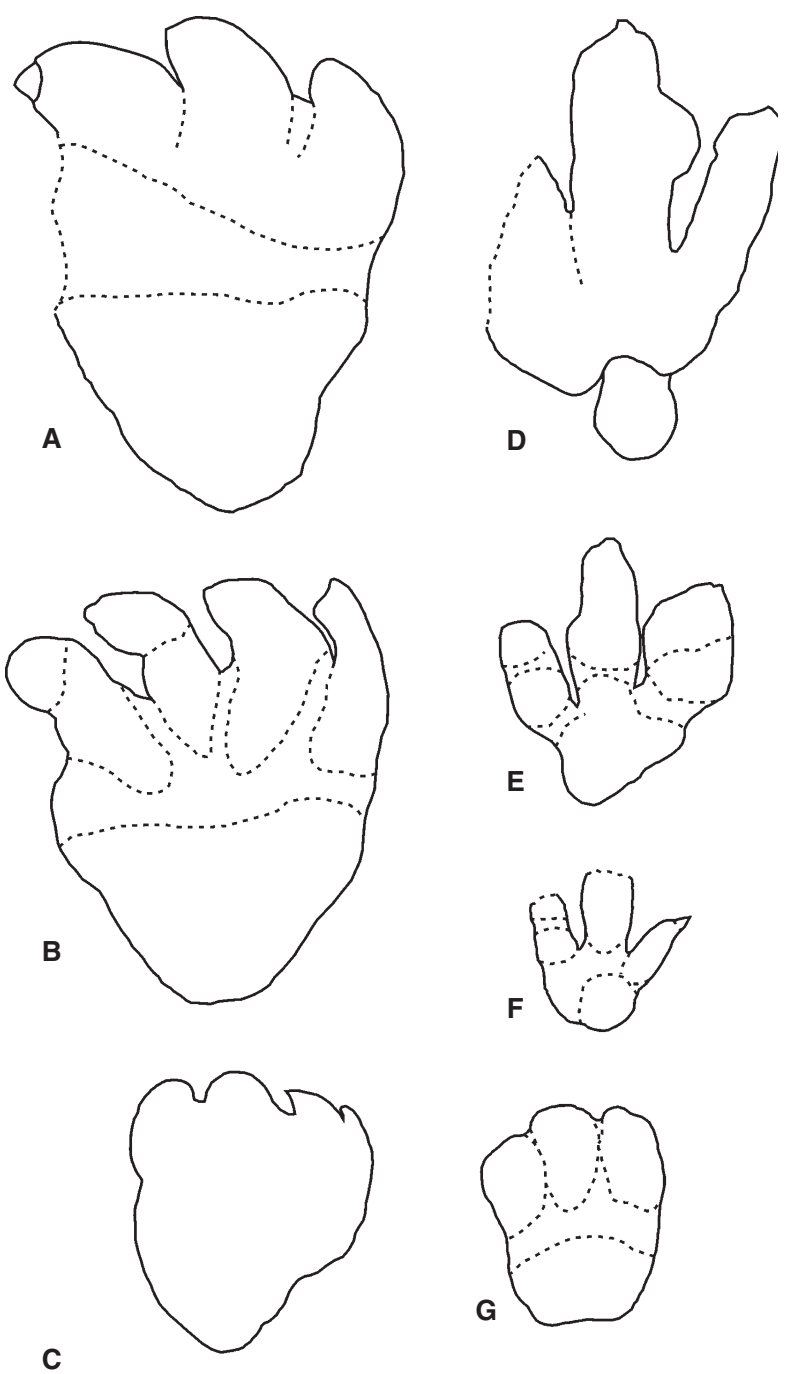

1 metre

Fig. 11. Comparative silhouettes of the sizes and types of tracks from Porto Dinheiro, attributed to sauropods A-C theropods D-F, and stegosaur G. All tracks drawn to same scale.

The dinosaur ichnofauna described from Porto Dinheiro comprises sauropod tracks ranging in length from 58 to $105 \mathrm{~cm}$, a stegosaur track $42 \mathrm{~cm}$ long and theropod tracks from 30 to $79 \mathrm{~cm}$ in length (Fig. 11). When the ichnofauna from Porto Dinheiro are combined with the trackfauna previously described from the Lourinhã Formation (Antunes \& Mateus 2003; Milàn et al. 2005; Mateus \& Milàn 2008), the total known dinosaur ichnofauna comprises sauropods, ornithopods, theropods and thyreophorans. All the tracks except for the stegosaur tracks occur in sizes from medium to gigantic. Contemporaneous coastal and deltaic deposits of Asturias, northern Spain, likewise contains diverse dinosaur ichnofaunas (GarcíaRamos et al. 2006), but in addition to the dinosaur tracks, they also contain tracks from turtles, crocodiles and pterosaus (Avanzini et al. 2005, 2007; GarcíaRamos et al. 2006; Lockley et al. 2008). The Middle Jurassic Cleveland Basin of the Yorkshire Coast of England contains a similar diverse trackfauna including tracks from dinosaurs, turtles and crocodiles (Whyte et al. 2007). Abundant swimming traces attributed to dinosaurs, crocodilians, turtles and fish has in addition been described from the Yorkshire Coast. In contrast to the Upper Jurassic track record of Lourinhã, Portugal and Asturias in Spain, the only skeletal remains found associated with the rich trackfauna from the Middle Jurassic Yorkshire Coast of England, is a single partial vertebra (Romano \& Whyte 2003). No swimming traces or tracks from either crocodiles or turtles have so far been found in the Lourinhã Formation, but teeth and skeletal remains of both are commonly encountered (Mateus 2006), and it is expected that crocodile, pterosaur and turtle tracks will turn up during future ichnological research in the area.

This diversity of tracks in the Lourinhã Formation reflects a diverse dinosaur fauna, which is also represented by abundant well-preserved skeletal remains of dinosaurs and other vertebrates (Antunes \& Mateus 2003; Mateus 2006). This makes the Lourinhã Formation an important taphonomic window into the Upper Jurassic continental ecosystem.

\section{Conclusion}

In summary, we conclude that:

1. The Lourinhã Formation (Kimmeridgian/Tithonian) contains a rich and diverse dinosaur ichnoand somatofossil fauna, and is important for understanding of the Upper Jurassic continental ecosystem and faunal assemblages.

2. The Porto Dinheiro locality (Lourinhã Formation, Upper Kimmeridgian/Lower Tithonian) shows a diverse dinosaurian ichnofauna comprising tracks from stegosaurs, medium- and large-sized theropods, and medium- to large-sized sauropods.

3. New sauropod tracks provide new information about soft tissue anatomy of the sauropod feet in that one track has preserved the perfect cast of the ungual insertion into the soft tissue of the digit. Other tracks have preserved evidence of the palmar surface of the foot being divided into distinct pads, and impressions of hexagonal skin pattern, with skin scales of $2-3 \mathrm{~cm}$, adding to the scarce reports of sauropod autopodia skin impressions, and in great detail showing the distribution and arrangement of the skin tubercles. 
4. A new large theropod track, tentatively attributed to Torvosaurus, is among the largest theropod track known from the Upper Jurassic. For this theropod track $79 \mathrm{~cm}$ (possibly $96 \mathrm{~cm}$ ) in length, the trackmaker would have had a hip height around $3.5 \mathrm{~m}$.

5. Despite the scarce global record, new stegosaur pes tracks are reported here.

Acknowledgements. - The research of JM was supported by the Danish Natural Science Research Council, and OM by fellowship SFRH/BPD/25291/2005 of the Portuguese 'Fundação para a Ciência e Tecnologia'. Finn Surlyk, Department of Geography and Geology, University of Copenhagen kindly read and made useful suggestions to an early draught of the manuscript. Dennis Ry Hansen, Department of Geography and Geology, University of Copenhagen was of great assistance during the hunt for tracks. We thank the Municipality of Lourinhã and Horácio Mateus for the collecting efforts. Two anonymous reviewers provided helpful comments and suggestions to the manuscript.

\section{References}

Alexander, R.Mc.N. 1976: Estimates of speeds of dinosaurs. Nature 261, 129-130.

Alves, T.M., Manuppella, G., Gawthorpe, R.L., Hunt, D.W. \& Monteiro, J.H. 2003: The depositional evolution of diapir- and fault-bounded rift basins: examples from the Lusitanian Basin of West Iberia. Sedimentary Geology 162, 273-303.

Antunes, M.T. 1998: A new Upper Jurassic Paulchoffatiid multituberculate (Mammalia) from Pai Mogo, Portugal. Memórias da Academia das Ciências de Lisboa 37, 125-153.

Antunes, M.T. \& Mateus, O. 2003: Dinosaurs of Portugal. Comptes Rendus Palevol 2, 77-95.

Antunes, M.T., Taquet, P. \& Ribeiro, V. 1998: Upper Jurassic dinosaur and crocodile eggs from Pai Mogo nesting site (Lourinhã, Portugal). Memórias da Academia das Ciências de Lisboa 37, 83100.

Avanzini, M., García-Ramos, J.C., Lires, J., Menegon, M., Piñuela, L. \& Fernández, L.A. 2005: Turtle tracks from the Late Jurassic of Asturias, Spain. Acta Palaeontologica Polonica 50, 743-755.

Avanzini, M., García-Ramos, J.C., Lires, J., Piñuela, L. \& Lockley, M.G. 2007: Crocodylomorph tracks from the Late Jurassic of Asturias (Spain). Ichnos 14, 143-153.

Azerêdo, A.C., Wright, V.P. \& Ramalho, M.M. 2002: The MiddleLate Jurassic forced regression and disconformity in central Portugal: eustatic, tectonic and climatic effects on a carbonate ramp. Sedimentology 49, 1339-1370.

Bonaparte, J. \& Mateus, O. 1999: A new diplodocid, Dinheirosaurus lourinhanensis gen. et sp. nov., from the Late Jurassic beds of Portugal. Revista del Museo Argentino de Ciencias Naturales 5, 13-29.

Dantas, P., Santos, V.F., Lockley, M.G. \& Meyer, C.A. 1994: Footprint evidence for limping dinosaurs from the Upper Jurassic of Portugal. Gaia 10, 43-48.

Dantas, P., Sanz, J.L., da Silva, C.M., Ortega, F., dos Santos, V.F. \& Cachao, M. 1998: Lourinhasauras n. gen. Novo dinossaurio sauropode do Jurassico superior (Kimeridgiano superior-Titoniano inferior) de Portugal. V Congresso Nacional de Geologia, Lisboa, 91-94.

Escaso, F., Ortega, F., Dantas, P., Malafaia, E., Pimentel, N.L., Pereda-Suberbiola, X., Sanz, J.L., Kullberg, J.C., Kullberg, M.C. \& Barriga, F. 2007: New evidence of shared dinosaur across Upper Jurassic proto-North Atlantic: Stegosaurus From Portugal. Naturwissenschaften 94, 367-374.

Galton, P.M. 1980: Partial skeleton of Dracopelta zbyszewskii n.gen. and n.sp., an ankylosaurian dinosaur from the Upper Jurassic of Portugal. Géobios 13, 451-457.
Galton, P.M. \& Jensen, J.A. 1979: A new large theropod dinosaur from the Upper Jurassic of Colorado. Brigham Young University Geological Studies 26, 1-12.

García-Ramos, J.C., Lires, J. \& Piñuela, L. 2002: Dinosaurios: Rutas por el Jurásico de Astúrias, 204 pp. Group Zeta, Lugones Astúrias.

García-Ramos, J.C., Piñuela, L. \& Lires, J. 2006: Atlas del Jurásico de Astúrias, 225 pp. Ediciones Nobel, Oviedo.

García-Ramos, J.C., Piñuela, L., Ruiz-Omeñaca, J.I. \& PeredaSuberbiola, X. 2008: Costas Jurásicas frecuentas por estegosaurios. In Ruiz-Omeñaca, J.I., Piñuela, L. \& García-Ramos, J.C. (eds): Libro de Resúmes de las XXIV Jornadas de la Sociedad Española de Paleontología, 33-34. Colunga, Astúrias.

Gierlinski, G. \& Sabath, K. 2002: A probable stegosaurian track from the Late Jurassic of Poland. Acta Palaeontologica Polonica 47, 561-564.

Hill, G. 1989: Distal alluvial fan sediments from the Upper Jurassic of Portugal: controls on their cyclicity and channel formation. Journal of the Geological Society of London 146, 539-555.

Kullberg, J.C., Rocha, R.B., Soares, A.F., Rey, J., Terrinha, P. \& Martins, L. 2006: A basia Lusitania: estratigrafia, paleogeografia e tectónia. In Dias, R., Araújo, A., Terrinha, P. \& Kulberg, J.C. (eds): Geologia de Portugal no Contexto de Ibería, 317-368. Universidade Évora.

Lapparent, A.F.de. \& Zbyszewski, G. 1957: Les dinosauriens du Portugal. N. S. Mémoires du Service Géologique du Portugal $2,1-63$.

Leinfelder, R.R. 1987: Multifactorial control of sedimentation patterns in an ocean marginal basin: the Lusitanian Basin (Portugal) during the Kimmeridgian and Tithonian. Geologische Rundschau 76, 599-631.

Lires, J., García-Ramos, J.C. \& Piñuela, L. 2002: Ichnitas de estegosaurios en los ambientes deltacios del Jurásico Superior de Asturias. In Pérez-Lorente (ed.): Libro de Resúmenes del Congreso Internacional Sobre Dinosaurios y Otros Reptiles Mesozoices de España, 30-31. Universidad de La Rioja.

Lockley, M. 1991: Tracking Dinosaurs. A New Look at an Ancient World, 238 pp. Cambridge University Press, Melbourne.

Lockley, M. 2007: A tale of two ichnologies: the different goals and potentials of invertebrate and vertebrate (tetrapod) ichnotaxonomy and how they relate to ichnofacies analysis. Ichnos 14, 3957.

Lockley, M.G. \& Hunt, A.P. 1994: A track of the giant theropod dinosaur Tyrannosaurus from close to the Cretaceous/Tertiary Boundary, northern New Mexico. Ichnos 3, 213-218.

Lockley, M.G. \& Hunt, A.P. 1995: Dinosaur Tracks and Other Fossil Footprints of the Western United States, 338 pp. Columbia University Press, New York.

Lockley, M.G. \& Hunt, A.P. 1998: A probable stegosaur track from the Morrison Formation of Utah. Modern Geology 23, 331-342.

Lockley, M. \& Meyer, C. 2000: Dinosaur Tracks and Other Fossil Footprints of Europe, 323 pp. Columbia University Press, New York.

Lockley, M.G., Meyer, C.A. \& Santos, V.F. 1994a: Trackway evidence for a herd of juvenile sauropods from the Late Jurassic of Portugal. Gaia 10, 27-35.

Lockley, M.G., Farlow, J.O. \& Meyer, C.A. 1994b: Brontopodus and Parabrontopodus ichnogen. nov. and the significance of wideand narrow-gauge sauropod trackways. Gaia 10, 135-146.

Lockley, M.G., Meyer, C.A. \& Moratalla, J.J. 2000: Therangospodus: Trackway evidence for the widespread distribution of a Late Jurassic theropod with well-padded feet. Gaia 15, 339-354.

Lockley, M.G., García-Ramos, J.C., Pinuela, L. \& Avanzini, M. 2008: A review of vertebrate track assemblages from the Late Jurassic of Asturias, Spain with comparative notes on coeval ichnofaunas from the western USA: implications for faunal diversity in association with siliciclastic facies assemblages. Oryctos 8, 53-70.

Long, J.A. 1998: Dinosaurs of Australia and New Zealand and Other Animals of the Mesozoic Era, 188 pp. Harvard University Press, Cambridge.

Madsen, J.H. \& Welles, S.P. 2000: Ceratosaurus (Dinosauria, Theropoda), a revised osteology. Utah Geological Survey Miscellaneous Publications (MP-00-2), 1-80. 
Mateus, O. 1998: Lourinhanosaurus antunesi, a new Upper Jurassic allosauroid (Dinosauria: Theropoda) from Lourinhã, Portugal. Memórias da Academia das Ciências de Lisboa 37, 111-124.

Mateus, O.. 2005: Dinossauros do Jurássico Superior de Portugal, com Destaque Para os Saurísquios, 375 pp. Unpublished PhD thesis, Universidade Nova de Lisboa.

Mateus, O. 2006: Late Jurassic dinosaurs from the Morrison Formation, the Lourinhã and Alcobaça Formations (Portugal), and the Tendaguru Beds (Tanzania): a comparison. New Mexico Museum of Natural History and Science Bulletin 36, 223-231.

Mateus, O. 2007: Notes and review of the ornithischian dinosaurs of Portugal. Journal of Vertebrate Paleontology 27( suppl to 3), $114 \mathrm{~A}$.

Mateus, O. \& Antunes, M.T. 2001: Draconyx loureiroi, a new camptosauridae (Dinosauria: Ornithopoda) from the Late Jurassic of Lourinhã, Portugal. Annales Paléontologie 87, 61-73.

Mateus, O. \& Milàn, J. 2008: Ichnological evidence for giant ornithopod dinosaurs in the Upper Jurassic Lourinhã Formation, Portugal. Oryctos 8, 45-52.

Mateus, I., Mateus, H., Antunes, M.T., Mateus, O., Taquet, P. Ribeiro, V. \& Manupella, G. 1998: Upper Jurassic theropod dinosaur embryos from Lourinhã (Portugal). Memórias da Academia das Ciências de Lisboa 37, 101-110.

Mateus, O., Walen, A. \& Antunes, M.T. 2006: The large theropod fauna of the Lourinhã Formation (Portugal) and its similarity to that of the Morrison Formation, with a description of a new species of Allosaurus. New Mexico Museum of Natural History and Science Bulletin 36, 123-129.

Milàn, J. \& Chiappe, L.M. 2009: First American record of the Jurassic ichnogenus Deltapodus and a review of the fossil record of stegosaurian footprints. Journal of Geology 117, 343-348.

Milàn, J., Christiansen, P. \& Mateus, O. 2005: A three-dimensionally preserved sauropod manus impression from the Upper Jurassic of Portugal: implications for sauropod manus shape and locomotor mechanics. Kaupia 14, 47-52.

Moratalla, J.J., Sanz, J.L. \& Jimenez, S. 1988: Multivariate analysis on Lower Cretaceous dinosaur footprints: discrimination between ornithopods and theropods. Geobios 21, 395-408.

Pais, J. 1998: Jurassic plant macroremains from Portugal. Memórias da Academia das Ciências de Lisboa 37, 25-48.

Pereda-Suberbiola, X., Dantas, P., Galton, P.M. \& Sanz, J.L. 2005: Autopodium of the holotype of Dracopelta zbyszewskii (Dinosauria, Ankylosauria) and its type horizon and locality (Upper Jurassic: Tithonian, western Portugal). Neues Jahrbuch für Geologie und Paläontologie Abhandlungen 235, 175-196.

Platt, B.F. \& Hasiotis, S.T. 2006: Newly discovered sauropod dinosaur tracks with skin and foot-pad impressions from the Upper Jurassic Morrison Formation, Bighorn Basin, Wyoming, USA. Palaios 21, 249-261.
Rauhut, O.W.M. 2000: The dinosaur fauna from the Guimarota mine. In Martin, T. \& Krebs, B.. (eds): Guimarota - A Jurassic. Ecosystem, 75-82. Pfeil, Munchen.

Rauhut, O.W.M. 2001: Herbivorous dinosaurs from the Late Jurassic (Kimmeridgian) of Guimarota, Portugal. Proceedings of the Geologists' Association 112, 275-283.

Rauhut, O.W.M. 2003: A tyrannosauroid dinosaur from the Upper Jurassic of Portugal. Palaeontology 46, 903-910.

Romano, M. \& Whyte, M.A. 2003: Jurassic dinosaur tracks and trackways of the Cleveland Basin, Yorkshire: preservation, diversity and distribution. Proceedings of the Yorkshire Geological Society 54, 185-215.

Santos, V.F., Lockley, M.G., Meyer, C.A., Carvalho, J., Galopim de Carvalho, A.M. \& Moratalla, J.J. 1994: A new sauropod tracksite from the Middle Jurassic of Portugal. Gaia 10, 5-13.

Thulborn, R.A. 1973: Teeth of ornithischian dinosaurs from the Upper Jurassic of Portugal, with description of a hypsilophodontid (Phyllodon henkeli gen. et sp. nov.) from the Guimarota lignite. Memória Serivoços Geológicos de Portugal (Nova Série) 22, 89-134.

Thulborn, T. 1990: Dinosaur Tracks, 410 pp. Chapman \& Hall, London.

Whyte, M.A. \& Romano, M. 1994: Probable sauropod footprints from the Middle Jurassic of Yorkshire England. Gaia 10, 1526.

Whyte, M.A. \& Romano, M. 2001: Probable stegosaurian dinosaur tracks from the Saltwick Formation (Middle Jurassic) of Yorkshire, England. Proceedings of the Geologist's Association 112, 4554.

Whyte, M.A., Romano, M. \& Elvidge, D.J. 2007: Reconstruction of Middle Jurassic dinosaur- dominated communities from the vertebrate ichnofauna of the Cleveland Basin of Yorkshire, UK. Ichnos 14, 117-129.

Wright, J.L.. 2005: Steps in understanding sauropod biology In Curry Rogers, K.A. \& Wilson, J.A. . (eds): The Sauropods: Evolution and Paleobiology, 252-285. University of California Press, Berkeley.

Yagüe, P., Dantas, P., Ortega, F., Cachão, M., Santos, F.A.M., Gonçalves, R. \& Lopes, S. 2006: New sauropod material from the Upper Jurassic of Areia Branca (Lourinhã, Portugal). Neues Jahrbuch für Geologie und Paläontologie 240, 313342.

Yang, S.-Y., Yun, C.S. \& Kim, T.W. 2003: Pictorial Book of Korean Fossils, 419 pp. Academy Book Company, Seoul.

Zinke, J. 1998: Small theropod teeth from the Upper Jurassic coal mine of Guimarota (Portugal). Palaontologische Zeitschrift 72, 179-189. 